\title{
KOŚCIÓł DOMOWY W OKRESIE PRZEDKONSTANTYŃSKIM
}

Wiadomo, ze okres porstawania wielkich budowli kościelnych wizzze się z przełomem konstantyńskim, a więc uznaniem chrześcijaństwa za religie oficjalną. Tak więc w II 1 III w. po Chr. jedynie dom prywatny pozostawał głównym miejscem gromadzenia się chrześci-

$x$ Jest totfumaczenie trzeciego rozdziału pracy Hansa - Josefa Klaucka pt. "Hausgemeinde und Hauskirche im Pruhen Christentum", Stuttgart 1981, 69-81/Stuttgarter Bibelstudien 103/. W jej recenzji umieszczonej w AK $75 / 1983 / t .101,300-304$, podaliśmy równiez bibliografie dotycząca kościoła domowego/zob. przyp. 3, s.301-302/, którą tutaj uzupełniamy dzięk1 uprzejmości Prof. Klaucka, który nadesłał polskiemu tłumaczowi pewne uzupełnienia. do swojej ksiazzki wraz z wykazen najnowszej literatury dotyczacej tego przedmiotu. Noty tłumacza oznaczać będziemy litera "a" dołaczonz do cyery przypisu autora. Weryfikacji tłumaczenia dokonat ks.S. Longosz.

BIBLIOGRafiA: R.Banks, Paul's Idea of Communtty: The Early House Churches in their Historical Setting, Exeter 1980; D. von Allmen, La familie de Dieu. La symbolique familiale dans le paulinisme, Fribourg-Gottingen 1981; J.K.Coyle, Empire and Eschaton: The Early Church and the Question of Domestic Relationships, "Eglise et théologie" 12/1981/35-94; J.H.Elliott, A Home for the Homeless. A Sociological Exegesis of 1 Peter. Its Situation and Strategy, Philadelphia 1981; N.Provencher. Vers une thóologie de la pamilie: l'Eglise domestique, "Église et théologle" 12/1981/9-34; H.-J.Klauck, Neue Literatur zur urchristichen Hausgemeinde, "Byzant'nische Zeitschrift" 26/1982/288-294; H. -J.Klauck, The house-church as way of life, "Theology Digest" 30/1982/153-158; W. Vogler, Die Bedeutung der urchristichen Hausgemelnden ftr die Ausbre1tung des Evangeliums, "Theologische Literaturzeitung" 107/1982/786-794; L.M. White, Domus Ecclesiae: Domus Del. Dissertation, Yale University 1982; H.Bússo, Gottesdienst in "Gruppe" und "Hausgemeinde". Tradition und Aupgabe, w: Freude am Gotteadienst, Stuttgart 1983, 243-252; G. Dautzenberg /Hrsg./, Die Frau im Urchristentum, Freiburg 1983; H.M.I.Gevaryahu, Privathauser als Versammlungsstat on von Meister und Jingern, "Annual of the Swedish Theological Institute" 12/1983/5-12; J.Gnilka, Die neutestamentliche Hausgemeinde, w: Freude am Gottesdienst, Stuttgart 1983, 229-242; F.L.Hossfeld, Die alttestamentliche Familie vor Gott, tamze, 217-228; A.Lancelott1, La casa di Pietro a Cafarnao nei Vangeli sinottici. Ledazione e tradizione, "Antonianum" 58/1983/48-69; R.Aguirre, La casa como estructura base del cristianismo primitivo: 
Jańskiej gminy-wspólnoty ${ }^{1}$; na tym zasadza się zwiazek z pierwotnymi wspólnotami domowymi, do których będziemy wracać, opierając się na przekazie niektórych tradycji legendarnych. W okresie tym wzmogły się bez watpienia tendencje, które ostatecznie doprowadziły do zaniku wspólnot domowych na korzyść pełnej budowli kościelnej. Wí źródłach występuje niekiedy określenie "doinus ecclesiae"1a, które w wolnym tłumaczeniu moźna oddać przez "kościół domowy". W ścisłym znacze n1u było ono stosowane na określenie obszernych zabudowaí lub pomieszczeń mieszkalnych, będących częściowo jeszcze w posiadantu osoby prywatnej, a częściowo już społeczną Własnościá gminy, w których znajdowało się osobne pomieszczenie kultyczne, wyłączone ze świeckiego użycia, a prócz tego mieszkania dla kleru 1 pokoje służące innym formom życia wspól notowego /np. agapom/. Już w czasach przedkonstantyńskich moźna mówić o pierwszych budowlach kościelnych, do których stosơano określenia "bazylika" lub "dom Kościoła", mimo ze rozmiar budownictwa był jeszcze skromny.

Kozwój uzależniony był od uwarunkowań czasu i miejsca. Można sobie wyobrazić najrozmaitsze możliwości pośrednie i kombinacje, ale z powodu braku pewnych źródeł są one trudne do przedstawienta. Okresy wzmoźonych prześladowań przez władze rzymskie charakteryzuja swoiste prawa, poniewaz powszechnie znane obiekty zgromadzeń chrzescijańskich były konfiskowane, a potem znowu przekazywane w rece ro-

les iglesias domesticas, "Estudios Eclesiást1cos" 59/1984/27-51.

1 Por. W. Kordorf, Was wissen wir tber die christlichen Gottesdienstrâme der vorkonstantischen 7eit? "Zeitschrift fur die neutestamentliche Wissenschaft" 55/964/110-128: "die ersten dre1 Jahrhunderte sind die Zeit der Hauskirchen"/s.111/. Por. takze: A.Harnack, Die Mission und Ausbreitung des Christentums in den ersten drei Jahrhunderten, Bd.2, Leipzig 1924, 611-618; J.P.Kirsch. Die vorkonstantinischen christlichen Kultusgebaude im Lichte der neuesten Entdeckungen im Osten, "ibmische Quartalschrift" 41/1933/ 15-18.

1a Por. B.Filarska, Poczłłtki architektury chrześcijańskiej, Lublin 1983, 23-36/= "Domy Kościoła"/. 
dziny. Niżej wymienione przykłady zostaniz objaśnione przy pomocy zestawienia $i$ onówienia pewnych dokumentów o proweniencji literackiej $i$ archeologicznej. Nie należy jednak przy tym oczekiwać pełnej kompletności.

\section{Swiadect:a literackie}

Zaczniemy od niezwykle cennych z historycznego punktu widzenia aht męczeńskich chrześcijańskiego filozofa Justyna/stracony w izymie ok. 165 r. po Chr.l i jego towarzyszy. Na pytanie rzymskiego prefekta Hustyka: "Gdzia się zbieracie / $\cup \nu \varepsilon \rho \chi \varepsilon \sigma \theta \varepsilon /$ ?", odpowiedział co następuje:

"Tam, gdzie kaźdy chce i może. Czy ty może myślisz, że my wszyscy zbieramy sie na tym samym miejscu?

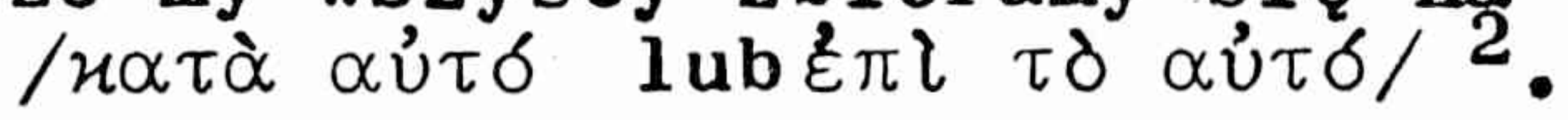

Po zlokalizowaniu swego miejsca zamieszkania niedaleko znanego rzymskiego uzdrowiska ${ }^{3}$, mówił dalej:

"Nie znam żadnego innego miejsca zebrań / $\sigma u \nu \varepsilon \hat{\lambda} \varepsilon v \sigma \iota \nu /$ prócz tego. Jeśli któs chciał mnie tam znaleźć, dzieliłem siez nim słowem prawdy"4.

Z powyższego wynika, że mieszkanie Justyna w lzymie było centrum otwartej gminy-wspólnoty, zbierającej sie wokół niego oraz że mieście istniały również inne centra gmin, do których Justyn nie uczęszczał.

2 Martyrium Justini 3,1, ed. H.Musurilio/The Acts of the Christian

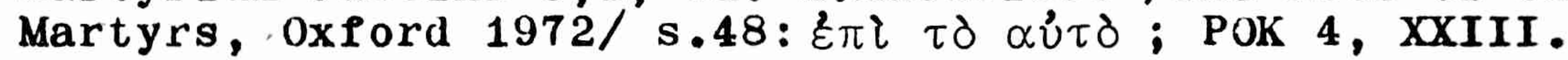

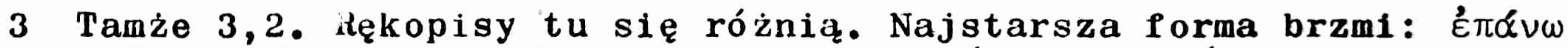

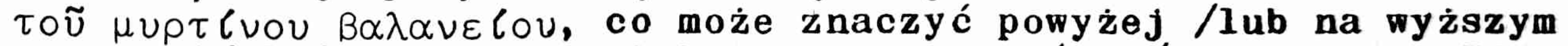
piętrze?/ łaźni mirtowej lub najwyższej łaźni /por. Passow II

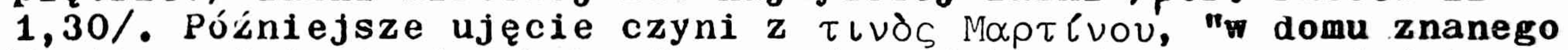
Martinusa" i stawia obok $\tau$ v $T \iota \mu \omega \tau \iota \nu \circ \cup \beta \alpha \lambda \alpha \nu \varepsilon l o v$, powyźj term Tymoteusza, które faktycznie istniały w ówczesnym izymie.

4 Martyrium Justini 3,3, Musurillo 48-50, POK 4, XXIV. 
Cytowany passus pozwala równocześnie zrozumieć jego własne pisma, w których stosuje słownictwo podobne Pawłowemu 1 Dziejom Apostolskim:

"W dniu zaś zwanym Dniem Słońca, odbywa się zebranie

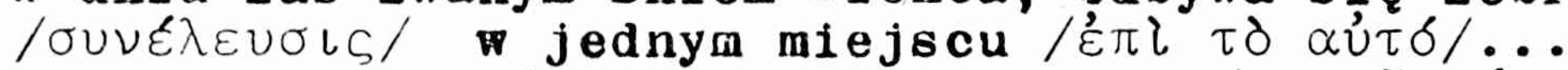

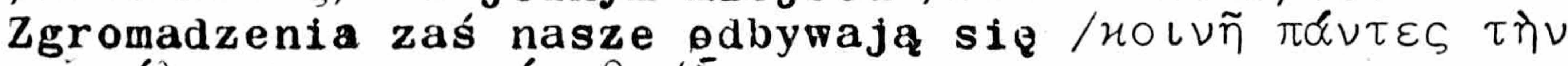

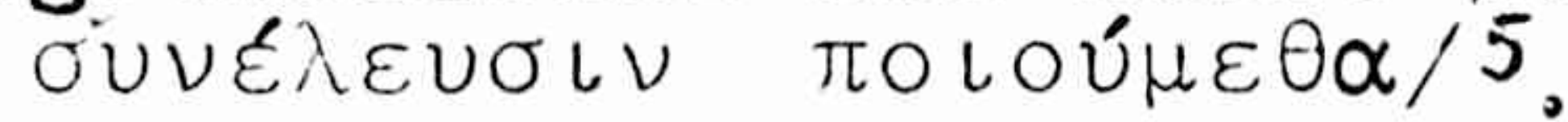

Swiadectwo Akt nie pozwala stwierdzić istnienia jakiegoś centralnego zgromadzenia lokalnej rzymskiej gminy-wspólnoty; równie dobrze moźna je odnieść do służby Bożej "domu Kościoła" wieszkaniu Justyna. W istocie bliscy jeszcze jesteśmy czasom nowotestamentainym.

W świat legendy wprowadzaja nas dwa następne swiadectwa. W "Passio św.Cocyli1" została umieszczona prośba świętej, by po męczeńskiej śmierci dom jej został zamieniony na kościół " W "Aktach Nereusza i Achillesa" zaś znajduje się wielce znaczące porównanie: męzczyźni 1 kobiety z całego miasta "nawracali sį̨ 1 chrzcili, tak że dom, w którym zatrzymywali się, stawaz się jakby kościołemn".

Swięty Hieronim komentując wiersz 22 Listu do Filemona, w którym Paweł prosi o gościnę w jego domu, czyni interesująca uwage: nie chodziło o przygotowanie gościny Pawłowi jako prywatnej osobie, lecz apostołowi. Poniewaz przybywał do nowego miasta, by przepowiadać Ukrzyzowanego 1 rozszerzać jeszcze nie słyszana nauke, przeto ze mzględu na oczekiwany napływ ludzi nalezało dysponować odpowiednio dużym 1 łatwo dostępnym domem dla wszystkich. Winien on być dostatecznie przestronny, a także położony z dala od teatrów czy innych zieszacych się złą opinia lokali rozrywkowych. Hieronim z pewnościa kieruje swą myśl do $\mathrm{Dz} 28,30 \mathrm{n}$, ozyli do mieszkania sw.Pawa w kzymie, które jego zdaniem odpowiadało tym wymogom ${ }^{8}$. Mamy tu więc przypomnienie starochrześcijańskiej misjl domowej /Hausmission/, z tym jedynie wyjątkiem, ze Hieronim kładzie akcent na praktycznych wymaganiach oficjalnej misji.

5 Justinus, Apologia I, 67,3 17 , PG 6,429 BC, POK 4,77 178 .

6 Vita et martyrium S.Caeciliae et sociorum 26, PG 116,180B.

7 Acta Nerei et Achille1 22, ed. Achell1s, TU 11,2, 22,5-9:

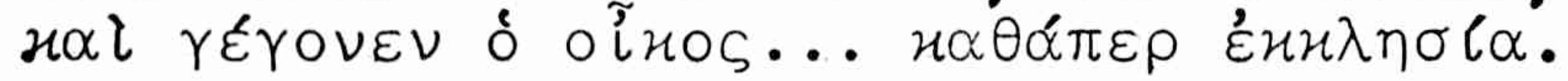

8 Commentarius in epistolam ad Philemonem 22, PL 26,616B: "... apostolo magis quam Paulo hospitium praeparandum est. Venturus 
Paralelna wypowiedź znajdujemy w IV wieku po Chr. u Amfilocha z Ikonium, który pisał o apostołach odbywających podróz misyjną:

"Przychodz11i często do domu pewnego Greka, który po nawróceniu przez nich do wiary woga, od razu uczyniz ze swego domu kośclół"9.

Dopisek zaś: "Tak się stało 1 waszym miescie dzięki Pawłowi Womu Onezyfora" wskazuje, ze informacju ta pochodz1 z "Akt Panła", które powstały częściowo w Ikonium oraz przejęy dalszy opis historii osób z listów pasterskich. Miejsca te "Aktach Pawła" brzmia analogicznie:

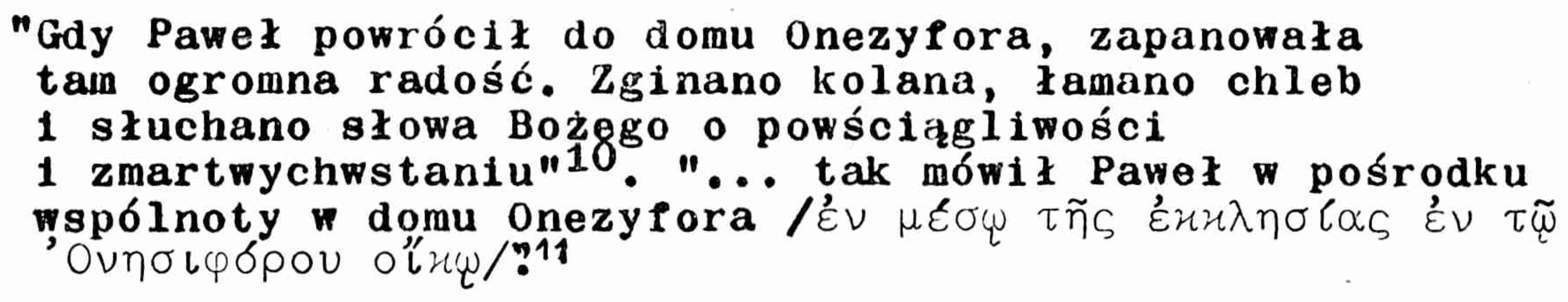

W końcowych jego paragrafach opisano powrót Tekli do domu Onezyfora, "gdzie Paweł głosił słowo Boże"; modliła się wśród łez "do Boga tego domu, by 1 dla niej zabłysło światło"12. Z kolei, według

ad novam civitatem, praedicaturus crucifixum, et inaudita dogmata delaturus, sciebat ad se plurimos concursuros; et necesse erat primum, ut domus in celebri esset urbis loco, ad quam facile conveniretur. Deinde, ut ab omni importunitate vacua: ut ampla, quae plurimos caperet audientium: ne proxima spectaculorum locis: ne turpi vicinia detestabilis: postremo ut in plano potius esset sita quam in coenaculo. Quam ob causam eum existimo etiam Romae in conducto mansisse biennium. Nec parva, ut reor, erat mansio, ad quam Judaeorum turbae quotidie conlluebant".

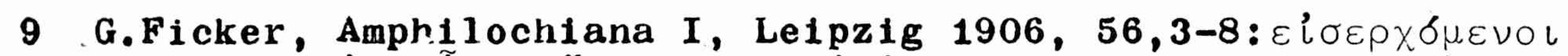

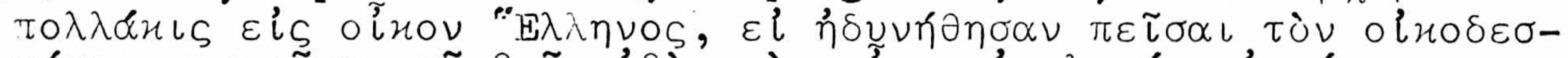

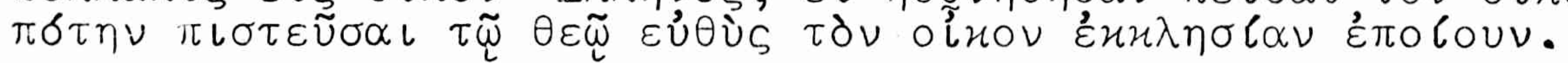

10 Acta Pauli et Theclae 5, ed. R.A.Lipsius - M.Bonnet /Acta Apostolorum apocrypha, Bd. 1-2, Hildesheim 1959/, Bd. 1,238,9-11.

11 Tamże 7, Lipsius - Bonnet Bd. 1,240, 6-7.

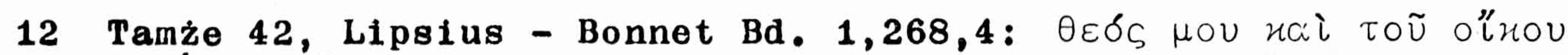

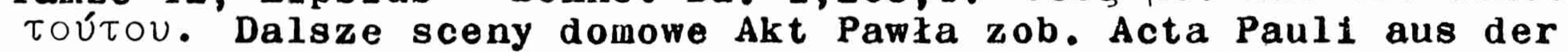
Heidelberger Koptischen Papyrushandschrift $5.316-7$, Neutestamentliche Apokryphen tbrzt E.Hennecke, Bd.2, Tabingen 19664, $256,262,263$. 
"Męczeństwa Pawła" Apostoł dla pełnienia swej działalności misyjnej wynają w poblizu Rzymu stodołę ${ }^{13}$. Ta koegzystencja chrześcijańskiego źycia w domu 1 ogólnego nawołującego do nawrócenia kazania wskazuje na występującą pomiędzy wspomnianymi relacjami różnicę w Dziejach Apostolskich Lukasza.

Przytoczyliśmy wyzej wszystkie te miejsca z apokryficznych akt apostolskich, gdzle Apostołowie prywatnym domu przepowiada1i, modlili sie, chrzcili i sprawowali uczte. Jan Apostoz przepowiadax wobec ogromnej liczby ludzi w domu Lykomedesa w Efezie 14 i pragną tam pełnic posługe charytatywną wobec starszych kobiet ${ }^{15}$. W domu Andronika, również wefie, przepowiadał, kterował modlitwą, sprawował Eucharystie $i$ nakładał ręce ${ }^{16}$. Tam takźe, zgodnie z zamysłem autora, mogła mieć miejsce ostatnia słuźba Boża Apostoła przed jego śmiercią, połazczona z mowa pożegnalną 1 ucztą eucharystyczną/Acta Joannis 106-110/.

Kompozycyjny moment "Akt Tomasza" stanowia liczne opowiadania o nawróceniach, które dokonymały się podczas chrztu, namaszczenia i Eucharystii. Opowiadający z reguły niezbyt wyraźnie zaznaczał miejsce takich wydarzeń: nie miał bowiem tym wyraźnego interesu. W większości wypadków dom jest milcząco suponowany, a tylko wiektórych miejscach wyrá́nie wskazany. Na przykład w rozdziale 65:

\section{"Swemu słudze Ksenofonowi zlecił Apostoł zebranie wszystkich na jednym miejscu. Kiedy zaś tłum sie zgromadzit, zaczał mówié"17.}

Okazało się później, że chodzi tu o dom oficera Sifora, w którym miało miejsce wiele epizodów ${ }^{18}$. On to przygotował Pawłowi

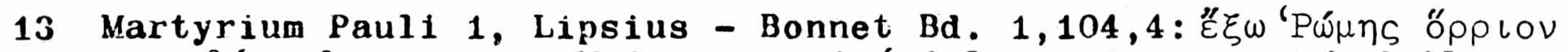
$\mu \iota \sigma \theta \omega ́ \sigma \alpha \sigma \theta \alpha \iota$ tam do niego - Moźna zauwazyc dalszy ciag: przychodz1t

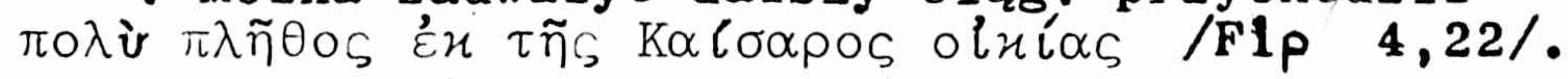

14 Acta Joannis 26, Lipsius - Bonnet Bd. 2, 1, 165,4-8.

15 Tamże 30, Lipsius - Bonnet Bd. 2,1, 167, 8-10.

16 Tamże 46, Lipsius - Bonnet Bd. 2,1, 173, 16-23; por. 62, Lipsius Bonnet Bd. 2,1, 181, 15-17.

17 Acta Thomae 65, Lipsius - Bonnet Bd. 2,2, 182, 10-13.

18 Taıże 81 i 105, Lipsius - Bonnet Bd. 2,2, 197, 9-8 i 217, 18-19. 
nawet triklinum/pokój z trzema łożaini/, jako lokal dla jego apostolskiej działalności ${ }^{19}$. Wśród miejsc inicjacji-mymienia sie nadto dom Charisa, gdzle sie nawróciła jego żona Mygdonia ${ }^{20}$ d dom królewskiego syna Wazana, gdzie się nawracali rodzina i odwiedzający goście 21. Zarówno "Akta Jana", jak i "Akta Tomasza" są niewątpliwie naznaczone wpływami gnostyckimi; jezeli to uwględnimy, to trzeba stwierdzić, że takie wspólnotowe życie gnostyckiego konwentyklu, jeśli moźna o takim mówić, rozgrywało się w domach prywatnych. Mozna nawet pójść dalej: gnostycy swiadomie ograniczyli je do domu, rezygnujac z budowania obiektów kultowych. Źródła gnostycikie poświęcają niestety tematowi temu zbyt mało miejsca. W gnostyckich ewangeliach brakuje elementu narracyjnego, który by sam mógl dostarczyé informacji o miejscu wydarzeń. W innych zaś traktatach do tego stopnia dominuje mitologia, kosmologia i teologia gnostycka, że na próżno szukać informacji o życiu wiary gnostyków.

Nie należy oczywiście oczek1wać historycznej wierności na interesujący nas temat ani od apokryficznych akt apostolskich, ani od dwóch notatek z utrzymanych stylu powieśclowym "Psoudoklementyn": W Antiochí potężny i wpływowy Teofil poświęcił swój dom na kościół, w którym wierny lud zbudował Piotrowi katedrę, by móc codziennie gromadzić się w dużej liczbie 1 słuchać jego słów 22 . Trypolisie Piotr szukał miejsca, by móc przepowiadać i dyskutować. Z pomoca wówczas przyszedł Maro, który zaofiarował mu swój rozległy dom z jeszcze wi gkszyni, leżącyini obok ogrodami. Gdy Piotr oglądał ten dom 1 ogród, tłum wcisnął się wkrótce do środka 1 zmusił go, by tam

19 Tamze 131, Lipsius - Bonnet Bd. 2,2, 238, 22-24; por. 138, Lipsius - Bonnet, Bd.2,2,245, 1-2: "obaj przyszli do domu oficera Sifora 1 znaleźli tam siedzącego $i$ nauczającego Judę".

20 Tamze 119-121, Lipsius - Bonnet, Bd. 2,2, 237, 9-10.

21 Tamże 155, Lipsius - Bonnet, Bd. 2,2, 264. 3 i 14.

22 Ps. Clemens, ilecognitiones X 71,2, GCS 51,371, 2-6, PG 1, 1453 B: "... Theofilus, qui erat cunctis potentibus in civitate sublimior, domus suae ingentem basilicam ecclesiae nomine consecraret, in qua Petro apostolo constituta est ab omni populo cathedra, et omnis multitudo cotidie ad audiendum verbum conveniens". 
pozostaz 1 nauczaz 23 .

Informacje te, mimo swej historycznej niepewności, posiadaja pewnaz wartość. Sile bowiom wyobraźni autora postawiono pewne granice. To, co można było odmalować 1 przekazać musiało mieć ścisłe oparcie w reczywistości. Gdyby faktycznie nie było wspólnot 1 domów Kościoła, to z pewnościa nle powstałyby takie opowiadania w "Pseudok lementynach".

W przypisywanym Lukianowi piśmie "Filopatris" jest informacja, że pewien poganín dostą̌ się na zebranie gminy domu bogatego chrześcijanina. W tekście brzmi to przesadnie: "do pozłacanego pomieszcze-

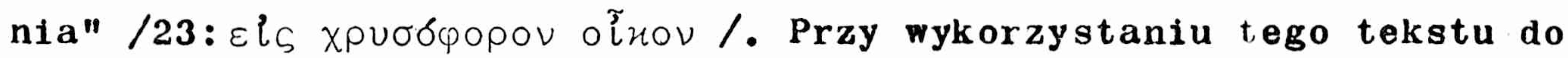
naszych refleksji należy podkreślić jego niepewną datację 1 niepewne autorstwo $^{24}$. Pewniejsze znaczenie ma tutaj zarzut jakiegoś pogańskiego przeciwnika chrześcijaństwa /Poreiriusza?/:

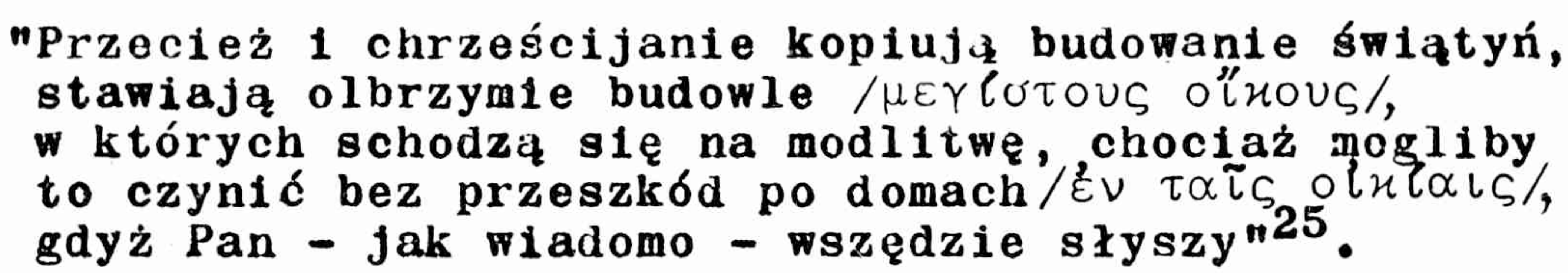

Ten zgoła nieoczekiwany zarzut poświadcza postępujące przechodzenie do budowy obiektów sakralnych, co zresztá było nieuniknione tak z powodów wewnętrznych, jak i zewnętrznych. Na k1edy mamy datować początki tego procesu wskazuje rozwój znaczenia, jakie otrzymał termin हนนน

"Przecież nie miejsce powinno być nazywane Kościołem, ani nie dom zbudowany z kamienia czy gliny ... Czymże więc jest Kościół? Swiętym zgromadzeniem żyjących

23 Tamże IV 6,1-3, GCS $51,149,15-25$, PG 1,1318 B: "... ot Maro ait: est mihi aedes amplissima, quae plus quam quingentos recipiat viros, est et hortus intra domum ... et subito omnis multitudo quasi ab aliquo evocata, cum festinatione ingressa est domum atque inde ad hortum prorupit, ubi jam stabat Petrus, considerans quis esset aptus ad disputandum locus:"

24 E. von Dobschatz, Philopatris, lealencyklopadie fur protestant1sche Theologie und Kirche ${ }^{3}$, XV 363-365.

25 Macartus Magnes, Apokrit1kos IV 21, TU 37,4,88, 19-23. 
w sprawiedliwości ... Tym jest Kośció, duchowy dom Bozy"26.

Wym samym niemal czasie termin $\varepsilon น \varkappa \lambda \eta \sigma l \alpha$, oznaczajacy aktualne zgromadzenie liturgiczne, wspólnotę lub Kośció zaczą być niepostrzezenie przenoszony na budowle przeznaczona do słuzby Bozej. Pośriadcza to pośrednio Klemens z Aleksandril:

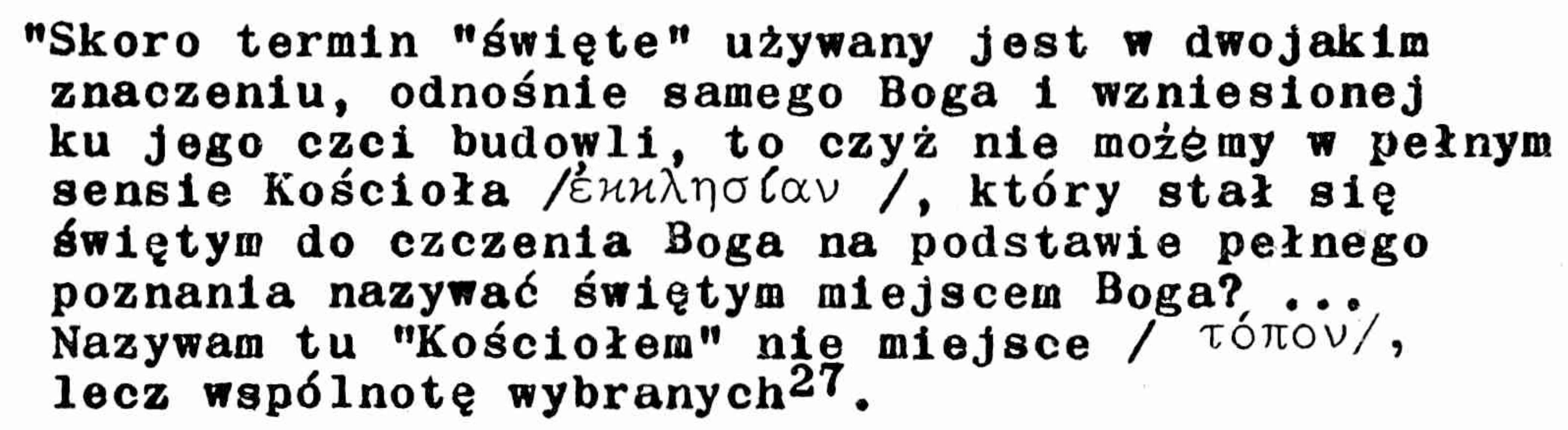

Wydaje się wątpliwe, by tekst stanowił bezpośredniz polemike Klemensa wobec tendencj1 zmierzających ku zmianie znaczenia ${ }^{28}$. Podobne przènyślenia spotkamy równiez przyszłości, a szczególnie ostre będa one tam, gdzie będzie chodziło, jak u Klemensa, o atak na pogaństwo, bóstwa w świątyni i 1ch posagi, czy teź, jak u Hipolita, o rozgraniczenie między fundacją a świątyniaz Starego Testamentu.

Ten sam stan rzeczy spotykamy u Laktancjusza, który przeciwstawia się określaniu świątyni Salomona terminem "ekklesia", bo nie składa się on z murów uczynionych ręka ludzḳa, lecz egzystuje jedynie sercach wierzacych ${ }^{29}$. Mimo to nie ma żadnych trudności, by mówić o budowlach kościelnych. W bityńskiej Nikomedil w obecności Dioklecjana 1 prefekta Galeriusza z oficerami 1 zołnierzami, gwardia pretoriańska podeszła pod kościół /ad ecclesiam/, otworzyła go, ułatwiła jego grabież $i$ zrównała z ziemia. Obaj cesarze przygladali sie z pazacu burzeniu owego wysoko położonego kościoła/in alto enim constituta ecclesia/30.

Zamiast tego określenia czytamy na innym miejscu u Laktancjusza o "conventicula" chrześcijan, które sa burzone ${ }^{31}$, i o loca ad

26 In Danielem I 17,6-8, GCS 1,28, 20-26.

27 Stromate1s VII $29,3 \mathrm{n}$, GCS $54,21,20-26$.

28 Tak F.W.Deichmann, Vom Templ zur Kirche, w: Mullus, Bonn 1964, 52-59.

29 Divinae Institutiones IV 13,26, CSEL 19, 324,5-10.

30 De mortibus persecutorum 12, 2-5, CSEL 27,186-187.

31 Tanże 15,7, CSEL 27, 189. 
quae antea convenire consuerant", które zostaná im zwrócone ${ }^{32}$. Według zaś innego przekazu z okresu prześladowań dioklecjaískich namiestnik udał się "ad domum, in qua christiani conveniebant"33.

Te nieścisłości i niepewności w słowntctwie nie powinny nas dziwié. Istnieja także i dzisiaj, gdy mówimy o Kościele, i często sa wykorzystywane $w$ homiletyce. Nawet u Euzebiusza, który chciał położyć kres tej dwuznaczności, różne terminy stoją obok siebie z ich wariantami znaczeniowyini. W Antiochii doszło do sporu pomiedzy Pawłem i Domnusem o godność biskupią 1 o "dom Kościoła"/Haus der Kirche/, whórym Paweł obrał sobie mieszkanie i nie chciał go opuścić; musiał interweniować cesarz ${ }^{34}$. W okresie prześladowań chrześcijańskie domy modlitwy były burzone ${ }^{35}$.

Tolerancyjne edykty cesarzy, które referuje Euzebiusz, zawieraja wskazania, żeby domy chrześcijan zwracać lub odbudowywać. w zwiazku z tym Euzebiusz Laktancjuszowe "conventiculum" oddaje

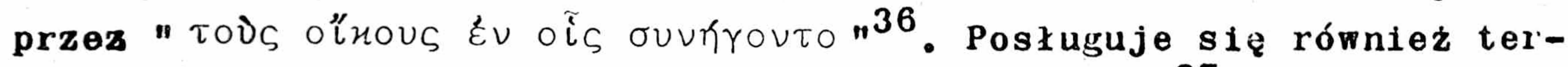

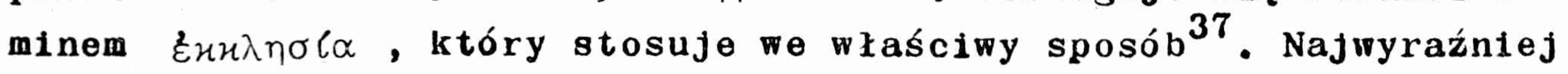
widać to na początku ósmej księgi:

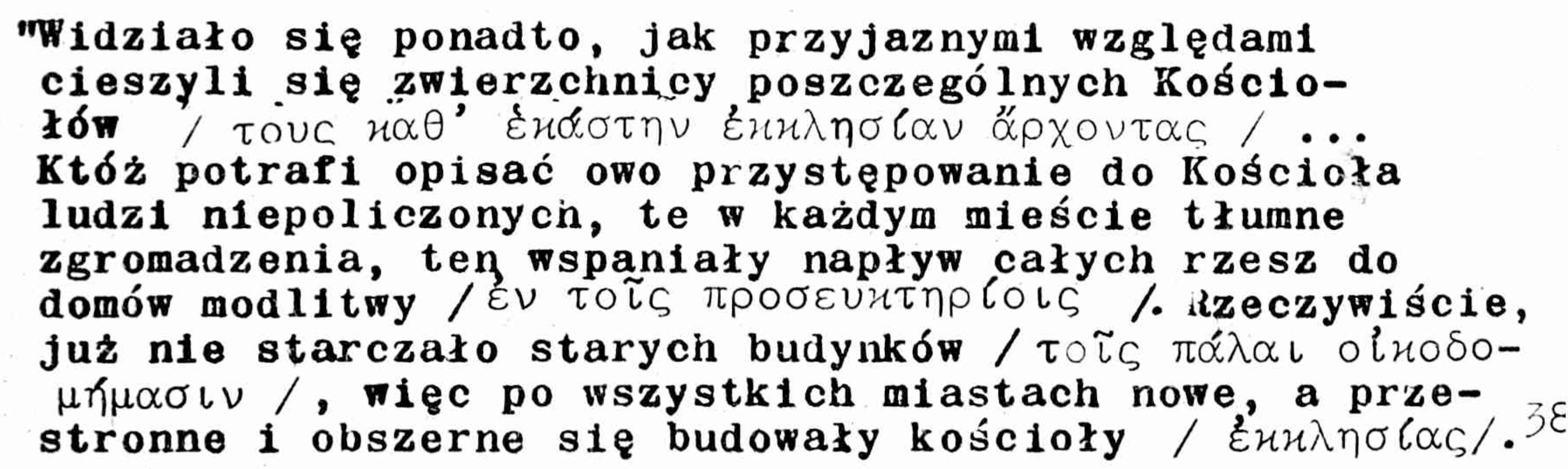

32 Tamże 48,7, CSEL 27,231, 9; Por. 34,4, CSEL 27,213.

33 Gesta apud Zenophilum CSEL 26,186,20; Por. F.J.D81ger: "K1rche" als Name Pur den christlichen Kultbau, ACh 6/1950/ 164 n.

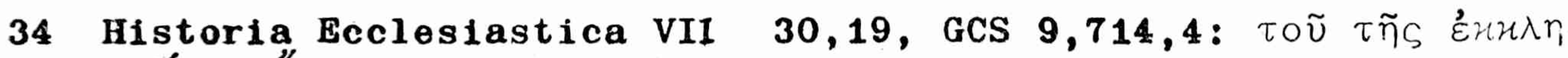
ol $\alpha S$ olhov.

35 Tamże VIII 2, 1, GCS 9,740,17:

36 Tamże VIII 17,9, GCS 9,794,16; Por. IX, 10,10, GCS 9,844,13.

37 Tamze VIII 17,1 , GCS $9,790,16 \mathrm{n}$.

38 Tamże VIII 1,5, GCS $9,736,22-738,6$, POK 3,360-361. 


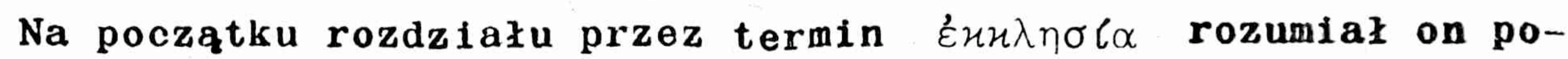
jedyncza wspólnotę-gminę/Einzelgemeinde/, przy końcu zaś budowlę. Terminy "zgromadzenie", "zebranie", "dom modlitwy" 1 "budowla" przenikają się więc majemnie.

W 312 r. po $C_{h r}$. Euzebiusz poświęcał po raz pierwszy jako biskup kościół w Tyrze ${ }^{39}$. W kazaniu, w którym posługiwał sie niezwykle często starotestamentalną 1 pogańską symboliką świątynną, wychwalał centralne miejsce owej budowli - najświetszy ołtarz ofiarny ${ }^{40}$. Hównolegle z przejściem od kultu zorganizowanego w obszarze prywatnym, do budowli skaralnych, dokonal sie dalszy rozwój od stołu jadalnego i rodzinnego, wokół którego zbierała się wspólnota domowa na Pamiątke Pana, do sakralnogo, zastrzeżonego kapłanow ołtarza ofiarnego ${ }^{41}$. Nie będziemy tu uwzględniac dalszych etapów i składnikóm tego procesu /np. wazczenia grobów męczenników/. Bezwzgledny koniec wyznaczył mu obradujący między 360 a 370 r. po Chr. synod Laodycel, zakazujacy sprawowania Eucharystii po domach: "tak biskupi, jak prezbiterzy nie powinni już więcej składac ofiary po domachn ${ }^{42}$.

\section{Swiadectwa archeologiczne}

Jeszcze gorzej niz ze źródłami pisemnymi przedstawia sie sprama $z$ archeologicznym materiałem dowodowym. Nie wynika to jednak z raktu niszczenia kościołów domowych w okresie prześladowań czy tez z faktu likwidacji lub poddawania ich zdecydowanym zmianom budowlanym, gdy juz nie słuzyły dotychczasowym zapotrzebowaniom gminy-wspólnoty. Ale 1 to co pozostało mespół z dokumentacja piśmienna wystarcza, by poświadczyć istnienie kościołów domowych.

W "Liber Pontificalis" wymienione jest 25 rzymskich kościołów, zwanych tituli /Titelkirchen/. Słowo "titulus" wskazuje na szczegól-

39 Tak Deichman, art.cyt., 58. Pytam się jednak nadal, czy to faktycznie tak Jasno wynika $z$ "Historla Ecclesiastica" $X, 3$ n.

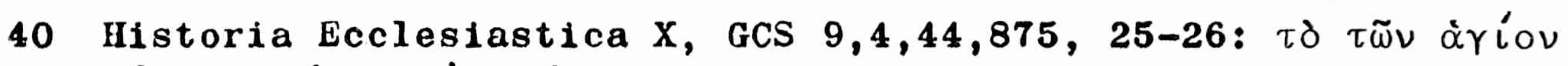

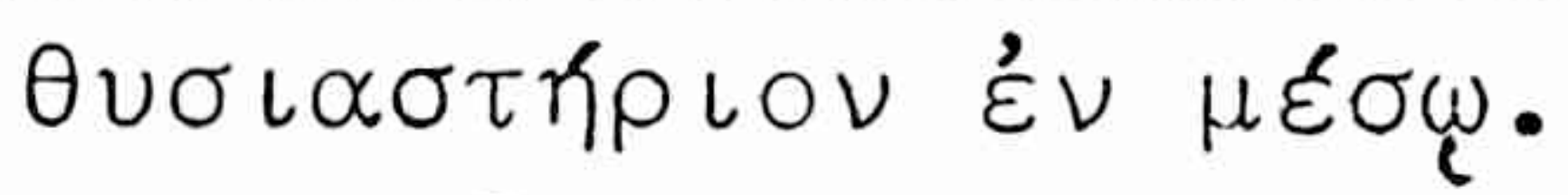

41 Por. F. Wieland, Mensa und Confessio. Studien aber den Altar der altchristlichen Liturgle I, Munchen 1906, $155 \mathrm{n}$.

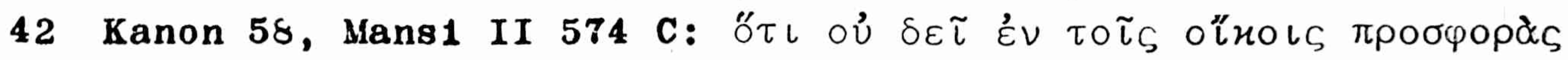


ną pozycję, odrębne stanowisko 1 wywodzi się od nazwiska wáściciela umieszczonego nad wejściem. Kieruje nas to ku czasom, gdy miejsca zebrań rzymskich chrześcijan oznaczane jeszcze były nazwiskami lch wcześniejszych właścicieli, którzy właśnie dla potrzeb gminy-wspólnoty budowali olbrzymie domy prywatne ${ }^{43}$. Nie wszystkie oczywiście kościoły tytularne moga sobie rościć prawo do określania tym starożyınym mianem. Jako pobożną legendę należy przyjąć, źe kościół San clemente zostal wybudowany na miejscu, gdzie stał dom Klemensa Hzymskiego. Kesztki bowiem domu z okresu przedkonstantyńskiego, ktore odkryto pod tym kościołem nie pozwalają na wysunięcie zbyt wielu wiosków. izym był gęsto zaludniony, stąd nowemu kościołowi musiaIy ustępować stare buỏowle. Dodatkowy problem stanowi mitreum zan clemente, które bezpośredniu lub oddzielone wąską ulicą sąsiadowa$10 \mathrm{z}$ kościołem domowym /M.J.Vermaseren, Corpus Inscriptionum et Monumentorum Religionis Mithriacae, Den Haag 1956-1960, 338/.

Inaczej przedstawiaja slę sprawy w przypadku kościoła SS.Giovanni e Paolo, starego titulus Byzantis. Tu bez watpienia można wskazać na lezacy pod kościołem typowy dom rzymski z pomieszczeniami handlowymi na parterze i mieszkalnymi w gónnych piętrach budowli. widać tu ponadto wyraźnie, zo obiekt ten był wykorzystywany jako siedziba wspólnoty-gminy, na co wskazują freski o motywach chrzescijańskich $i$ małe detale architektoniczne o charakterze liturgicznym. To samo można stwierdzić w przypadku kościołów SS. Silvestro e Martino ai Monti /titulus Equitii/i S. Anastasia; badanta archeologiczne stanowia tam wymowne potwierdzenie istnienia kościołów domowy $\mathrm{ch}^{44}$.

Przenieśmy się do Palestyny. Archeologowie z Kafarnaum przyjmuja, że dom Piotra został tam początkowo zamieniony na kośció domowy: a potem okresie wczesnobizantyńskim wzntesiono na nim ośm1o-

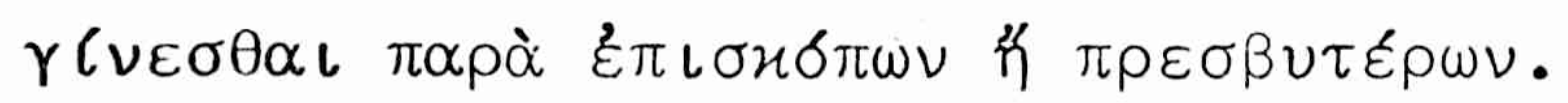

43 Por. J.P.Kirsch, Die r born 1918, $3 n$.

44 Opieramy sie na: J.M.Petersen, Hause-Churches in Rome, VC 23/1969/ 267-272; Kirsci, Die r8mischen Titelkirchen, dz.cyt., 21,26-29,39n., 42-44. Dalsze przykłady u K1rscha/s.54,61,65,73 n., 95-97, 115 n./, musza być jednak sprawdzone. Zbyt sceptycznie: C.II.Krealing, The 
kątnaz budowle, której resztki moźna ogladać do dziśs ${ }^{4}$. Moźna to zestawié z przekazem Ëgerii:

"Dom ksiecia apostołów Kafarnaum zamieniono na
kościół 46 Jego mury stoja do dziś w stanie nienaru-
szonym"4.

Hówniez w Amwas /Emaus/ zbudowano bazylike nad willowyn mieszkaniem w stylu rzymskim ${ }^{47}$, ale zarówno faktyczny stan rzeczy, jak 1 datowanie wydają się być sporne.

Takze po Konstantynie nie wszedzie wznoszono bazyliki. Klaus Gamber wskazuje, że do poczłtków 5 stulecia po Chr. wobszarze Alp 1 terenach naddunajskich istniał w dalszym ciagu "domus ecclesia" jako typ budowli mieszkalnej kościoła, nawizzujący cź̨̧ciowo do wcześniejszych planów domostwa. Omawia on między innymi przykłady z Akwilei, Budapesztu, Lorenzbergu, Lorch, Zillis 1 Stribach ${ }^{48}$. Kościół zaś domowy w Zurzach w Szwajcarii/ok.400 r. po Chr./, który wznosi sie na fundamentach rzymskiej wiejskiej willi 1 zajmuje trapezoidalny teren o wymiarach $9,1-9,9 \times 11,0-11,4 \mathrm{~m}^{49}$, jest niewiele większy od kościoła domowego w Dura Europos.

Ten najsłynniejszy z wszystkich kościołów domowych został odkryty w 1932 r. podczas wykopalisk w Dura Europos, mieście, w którym stacjonował rzymski garnizon 1 znajdowała sie twierdza graniczna nad środkowym biegiem Eufratu ${ }^{50}$. Jest on niczym innym, jak obszernym domem prywatnym, który można było dzięki niewielkim zabiegom adaptomać do nowych zadań. Sala główna dzięki zburzeniu ściany działowej została tak poszerzona/na ok. $5,15 \times 12,65 \mathrm{~m} /$, że mogła pomieścić

Christian Building, New Haven 1956, 129-134.

45 V.C.Corbo, Calarnao, t.1: Gli edifici della Città, Jerusalem 1975, 26-106.

46 Petri Diaconi, Liber de locis sanctis, jako Beda 16,2, CCL 175, 98, 7-10: "In Capharnaum autem ex domo apostolorum principis ecclesia racta est, qui parietes usque hodie ita stant, sicut fuerunt".

47 Por. Kirsch, Die vorkonstantinischen christlichen Kultusgeblude, art.cyt., 23-28.

48 Domus Ecclesiae. Die altesten Kirchenbauten Aquilejas sowie im Alpen- und Donaugebiet bis zum Beginn des 5. Jh. liturglegeschicht$11 \mathrm{ch}$ untergucht, Regensburg 1968, 33-62.

49 Tamze 54-56.

50 Źódłem miarodajnym okazuje się tu publikacja Kraelinga, The 
60-70 osób. W podwórzu dobudowano - uroczy szczegół - ubikację, i rozciagnięto naokoło nowe ławy 1 inne miejsca do siedzenia. Przede wszystkim zamioniono na baptysterium mniejsze pomieszczenie dzięki zalnstalowaniu chrzcielnicy 1 przyozdobieniu ścian malowidłami o tematyce biblijnej. Sugestia lietzmanna, ze owo pomieszczenie służyo sprawowaniu Eucharystii wałym gronie, a zbiornik/za mały jego zdaniem dla przyjmującego chrzest/miałby być grobem męczennika, podczas gdy pomieszczenie główne służło jedynie przepowiadaniu 1 gromadzeniu ${ }^{51}$, nie zyskała wiele aplauzu. Podczas penetracji archeologicznej nie natrafiono na zadne ślady kości lub innych relikwil, co nie przemawia za tezą Lietzmanna ${ }^{52}$. Ile zaś miejsca potrzeba do chrztu, jest po części kwestią gustu, moźna jednak powatpiewać czy Dura Europos praktykowano jeszcze pełne zanurzenie. Malowidła waptysterium są zresztá jedynymi chrześcijańskimi elementami w całym budynku. F sali bowiem zgromadzeń znajduja się resztki Presków dionizyjskich.

Prywatny dom został zbudowany w latach $232 / 233$ po Chr. na starych fundainentach $i$ to zy wacznie mieszkalnym przeznaczeniem. Chrześcijańska przebudowę należy datować na lata pomiędzy 240 a 245 po Chr. ${ }^{53}$ W 256 r. po Chr. Sassanidzi zdobyli 1 zniszczyli miasto; tak więc nowe obiekty jedynie kilkanaście lat spełniały swa rolę. Do ich zachowania przyczynił się ironicznie fakt, że zarówno ten budynek, jak 1 inne stojace wzdłuż murów miejskich, zostały zasypane nasypem ziemnym, majacym wzmacniać mury w ostatniej walce obronnej. Wzrost liczby chrześcijan, który poświadcza założenie kościoła, mógł się wiazzać z tyn, że wzmocnienie rzymskiego garnizonu wywołane militarnym zagrożeniem sprowadziło nowych wiernych do Dura.

Christian Building, dz.cyt., 4.

51 Recenzja: The Excavations at Dura Europos. Preliminary Reports 5-6 "Gnomon" 13/1937/234.

52 Por. C.Hopkins, The Discovery of Dura-Europos, New Haven 1979, 91.

53 Tak według Kraelinga, The Christian Building, dz.cyt., 34-39. Inaczej: A. von Gerkan, Die Pruhchristliche Kirchenanlage von Dura, "A8mische Quartalschrift" 42/1934/226 n.; E.Dinkler, DuraEuropos III, RGG II 290 . 
Nie wiemy, czy plerwszy waściciel sam narrócił się na chrześcijaństwo, czy teź sprzedaz chrześcijanom swój dom, choć pierwsza sugestia zdaje się być bardziej przekonująca. Nie wydaje się tez oczywiste, czy gmina chrześcijańska zajmowała ten dom juz przed jego przebudowa, czy teź byz on wcześniej domem wyłacznie mieszkalnym ${ }^{54}$. Także 1 w tym przypadku przyjęcie nieprzerwanego rozwoju wydaje sie być wysoce prawdopodobne. Zamieszkiwanie zaś domu przez jakáś rodz1nę już po jego przebudowle moźna prawie wykluczyć5 ${ }^{55}$; jest to bowiem etap przechodzenia od zamieszkałych domów prywatnych, które słuźyły równocześnie jako miejsca gromadzenia się chrześcijan, do czysto kościelnych budowl1, których powiązań z domami mieszkalnymi nie można negować.

Na tej samej ulicy, co omawiany kościól domowy, znajduje sie zydowska synagoga, oddalona zaledwie o dwa domostwa. Takze 1 ona wyrosła w dwóch etapach z domu prywatnego ${ }^{56}$. Kilkaset metrów dalej natrafiamy na dom z sanktuarium mitryjskim. Na całym wydzielonym terenie miasta znajdowało się co najmniej dwanaście, jeśli nie więcej, pogańskich świątyń pośw1ęconych wschodnim, greckim 1 rzymskim bóstwom. Interesujące okazałoby się równiez prześledzenie historii sanktuarium lokalnego boga Gad z Dura w powiazaniu z początkowym ośrodkiem tego kultu w domu mieszkalnym 57 .

Koścí́ł domowy, już sam wobie niezwykle fascynujący, obok synagogi domowej $i$ domu $z$ mitreum pośród barwnej wielości pogańskich miejsc kultu, stwarza niezwykle bogatą w symbolike sytuację, która dostarcza nam bodźca do skierowania uwagi na dalsze poszukiwania analog11 dla domowej gminy i domowego kościoła w środowisku pierwotnego chrześcijaństwa.

\author{
Lans-Josef Klauck - Wurzburg \\ Tłum. Marek Marczewski - Lublin
}

54 A. von Gerkan, Zur Lauskirche von Dura-Europos, w: Mullus, Mlunster 1964, 146. Uważa, że jego chrześc1jańskie wykorzystanie datować należy na $175 \mathrm{r}$. po Chr. Wydaje się to jednak bardzo problèmatyczne.

55 hordorf, Was wissen wir, art. cyt., 118 przyp. 31.

56 Por. C.H. Kraeling, The Synargogue, New llaven 1956, 3-3.3; Hopkins, dz. cyt., j.w. 126-136.

57 Hopkins, dz. cyt., J.w. 219: "The structure, which had begun as a typical well-to-do vurene house built around a court, had developed in four stages". 